\title{
Comparative Morphometry of the Olfactory Bulb, Tract and Stria in the Human, Dog and Goat
}

\author{
Morfometría Comparada del Bulbo, Tracto y Estría Olfatoria en el Humano, Perro y Cabra
}

"Boniface M. Kavoi \& **Hassanali Jameela

\begin{abstract}
KAVOI, B. M. \& JAMEELA, H. Comparative morphometry of the olfactory bulb, tract and stria in the human, dog and goat. Int. J. Morphol., 29(3):939-946, 2011.

SUMMARY: Morphometric parameters of olfactory brain components show species-dependent variations. However, the association of these parameters with olfactory function vis-à-vis ecological and evolutionary behaviors is poorly understood. In this study, a morphometric analysis of the olfactory bulb, tract and stria was carried out in three ecologically diverse animals comprising humans (primate), dogs (carnivore) and goats (herbivore) to elucidate differences in morphometry in relation to olfactory function. Using formalin-fixed brains, volumes and linear measurements of the olfactory structures were determined and correlated with those of cerebrum and the whole brain. The volume of the olfactory bulb was greatest in dogs, followed by goats and humans and constituted $0.31 \%, 0.18 \%$ and $0.01 \%$, respectively, of the brain volume. Similarly, the ratio of volume of the bulb, tract and stria to that of brain was $1.95 \%$ in the dog, $0.77 \%$ in the goat and $0.03 \%$ in the human. The width of the bulb was greatest $(\mathrm{p}<0.05)$ in dogs $(10.80 \pm 1.64 \mathrm{~mm})$ compared to goats $(8.25 \pm 0.96 \mathrm{~mm})$ and humans $(5.50 \pm 0.71 \mathrm{~mm})$, and accounted for a hemisphere breadth of $42.91 \%, 29.73 \%$ and $8.94 \%$ respectively. Interestingly though, the total length of the olfactory bulb, tract and striae increased in the order of goat (34.5 $\pm 1.30 \mathrm{~mm})$, human $(36.25 \pm 1.70 \mathrm{~mm})$ and $\operatorname{dog}(48.20 \pm 1.92 \mathrm{~mm})$, and constituted $21.47 \%, 51.87 \%$ and $72.30 \%$, respectively, of the hemisphere length. These results suggest that the morphometric adaptations of the olfactory components to olfactory function decline from the dog, to goat, to human, and this may be indicative of the varied olfactory functional needs in regard to the ecological diversity of these species.
\end{abstract}

KEY WORDS: Morphometry; Olfactory brain; Human; Dog; Goat.

\section{INTRODUCTION}

Primates, carnivores and herbivores represent three well known diverse groups of mammalian species with regard to evolutionary and behavioral ecology (Barton, 2006). In primates, the arboreal life, which calls for accurate perception of distances, has led to an increased reliance on stereoscopic vision at the expense of smell (Ross, 1995; Pough et al., 2005). Food acquisition in carnivores is by tracking and catching prey, an activity that demands for a well developed olfactory cue (Walker, 1975). Though plant eating in herbivores may require less of the olfactory sense, mediation of reproductive activities such as mating and estrus, and mother-infant interaction are dependent on olfaction (Gelez \& Febre-Nys, 2004; Lévy et al., 2004).

Several studies have associated ecological and behavioral factors to the substantial variation in the size and structure of brain areas of mammals (Barton, 1999; Barton et al., 1995; Finlay \& Darlington, 1995; Meisami \& Bhatnagar, 1998). The olfactory bulb, a part of the olfactory brain, serves as a relay station for primary olfactory neurons located within the nose. Here, axons of the primary neurons synapse with secondary neurons, mainly the mitral and tufted cells, within the olfactory bulb glomeruli (Field et al., 2003). On the anterior extremity of the cerebrum, the olfactory bulb sits on a flat band of white nerve fibers named olfactory tract, which continues posteriorly as the medial and lateral striae (Sisson \& Grossman, 1953).

Parameters of specific parts of brain show differences that reflect functional requirements between and within species (Kruska, 1988; Kaas \&Collins, 2001). Earlier work on olfactory brain morphometry focuses mainly on the bulb asymmetry (Heine \& Galaburda, 1986; Hirano et al., 1989) and sexual dimorphism (Byanet et al., 2009) within indivi-

\footnotetext{
* Department of Veterinary Anatomy \& Physiology, University of Nairobi, Nairobi, Kenya.

** Department of Human Anatomy, University of Nairobi, Nairobi, Kenya.
} 
dual species, allometry within genera (Gittleman, 1991), and the effects of disease on the bulb size (Turetsky et al., 2000; Turetsky et al., 2003). Besides, comparative data on the morphometry of the olfactory bulb and its projection structures in animals of diverse feeding and reproductive lifestyles is largely lacking. Furthermore, changes in parameters of certain brain parts have been attributed either to an increase in the number of neurons, the size of such neurons and/ or their connectivity (Kaas, 2000). In this study therefore, we examine the morphometry of the olfactory bulb, tract and stria in the human (primate), dog (carnivore) and goat (herbivore) in an attempt to elucidate the hypothesis that the variation in morphometry of these structures are reflective of the differences of these species with regard to olfactory requirements and ecology.

\section{MATERIAL AND METHOD}

Brains and olfactory parts. Five whole human brains, fixed by perfusion with $10 \%$ formalin, were obtained from the Department of Human Anatomy, University of Nairobi. These brains were obtained from bodies obtained for educational purposes as per the Human Anatomy Act.

Dog and goat brains, five for each species, were acquired from animals routinely purchased by the Department of Veterinary Anatomy and Physiology, University of Nairobi, for teaching purposes. After euthanizing these animals with pentobarbital sodium (200mg/ kg intra-peritoneally), the brains were perfused through the carotid artery with saline followed by $10 \%$ formalin. All protocols for the animals (dogs and goats) were approved by the Animal Care and Use Committee of the University of Nairobi.

The olfactory brain parts (olfactory bulb, tract and stria) are shown in a diagrammatic representation of the anterior portion of cerebrum (Fig. 1). The olfactory bulb occurs at the anterior extremity of each hemisphere where it sits on a flat band of nerve fibers, the olfactory tract. This tract is continued behind by two divergent bands designated medial and lateral olfactory striae. The latter is delineated from the underling lateral cerebral gyri by the sulcus rhinalis. At the angle of divergence of the striae occur the olfactory trigone, whose separation from the posteriorly positioned piriform lobe is by the lateral fossa. Figure 2 shows the olfactory structures (olfactory bulb, tract and striae) on brains of each of the three species studied.

Morphometry. Volumes of whole brains, and those of the olfactory bulb and olfactory tract and stria (dissected out from the brains) were determined using Water Immersion Volumetry (Scherle, 1970). A container filled with sufficient amount of saline was placed on a digital weighing balance, the structure completely immersed in the saline, and the change in weight reading taken to be equivalent to the volume of the brain.

Linear measurements of the cerebrum (on the brains in situ), and of the olfactory bulb and olfactory tract and

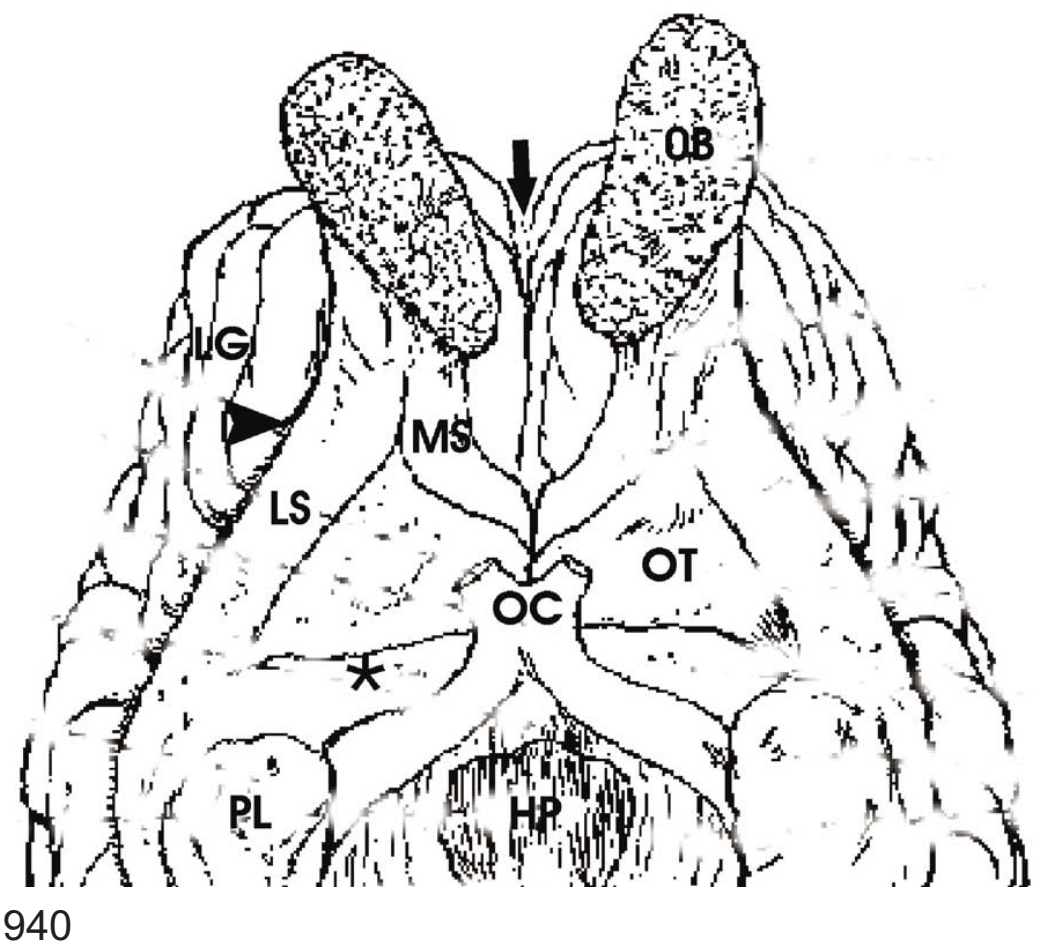

Fig. 1. A schematic representation of the inferior view of part of the cerebrum anterior to the hypothalamus (HP) showing the olfactory brain parts examined in the present study. The olfactory bulb $(\mathrm{OB})$ is located at the anterior extreme of the hemisphere, where it sits on the olfactory tract. Posteriorly, the tract extends as the olfactory stria, which diverges into a medial (MS) and a lateral striae (LS), with the olfactory trigone (OT) being positioned between the angle of divergence. At about the level of the optic chiasma (OC) and posterior to the olfactory trigone lies the lateral fossa $(*)$, which defines the boundary between the trigone and the piriform lobe (PL). Note also the separation of the two hemispheres by the longitudinal fissure (arrow) and the lateral stria from the lateral cerebral gyri (LG) by the sulcus rhinalis (arrow head). 
stria (separated from the brains) (Fig. 3), were determined using vernier calipers, thread and meter rule (Byanet et al.). Two trained laboratory technicians performed the measurements with intra and interobserver errors of $2 \%$ and $3 \%$ respectively.

The separation of the olfactory components from the brain was done as illustrated in Figures 3A\&C. To do this, the olfactory bulbs, tracts and striae were carefully dissected out (as a block) from the brain by making a blunt transverse incision along the sulcus rhinalis and extending medially to reach the inner face of the cerebral hemispheres, and detaching the block from the piriform lobe along the lateral fossa (Fig. 3A). The olfactory bulb was then detached from the underlying olfactory tract (Fig. 3C).

The following morphometric parameters were obtained for the human, goat and dog:- (i) volume of the whole brain, (ii) volume of the olfactory bulb alone, (iii) volume of the olfactory bulb, tract and stria, (iv) width and length of the cerebral hemisphere and (iv) width and length of the olfactory bulb alone and that of bulb, tract and stria combined.

Data analysis. Measurements of volumes and linear dimensions were repeated three times and mean values presented together with their SD (standard deviations). Comparisons of means between animal groups were done using the Student's ttest. Comparisons of morphometric values of the olfactory structures with those of the hemispheres and the brains were expressed as ratios (\%). In all cases, statistical significance was set at $\mathrm{p}<$ 0.05 .

\section{RESULTS}

The volume of the olfactory bulb was greatest in the $\operatorname{dog}\left(0.18 \pm 0.02 \mathrm{~cm}^{3}\right)$ followed by the goat $\left(0.17 \pm 0.01 \mathrm{~cm}^{3}\right)$,
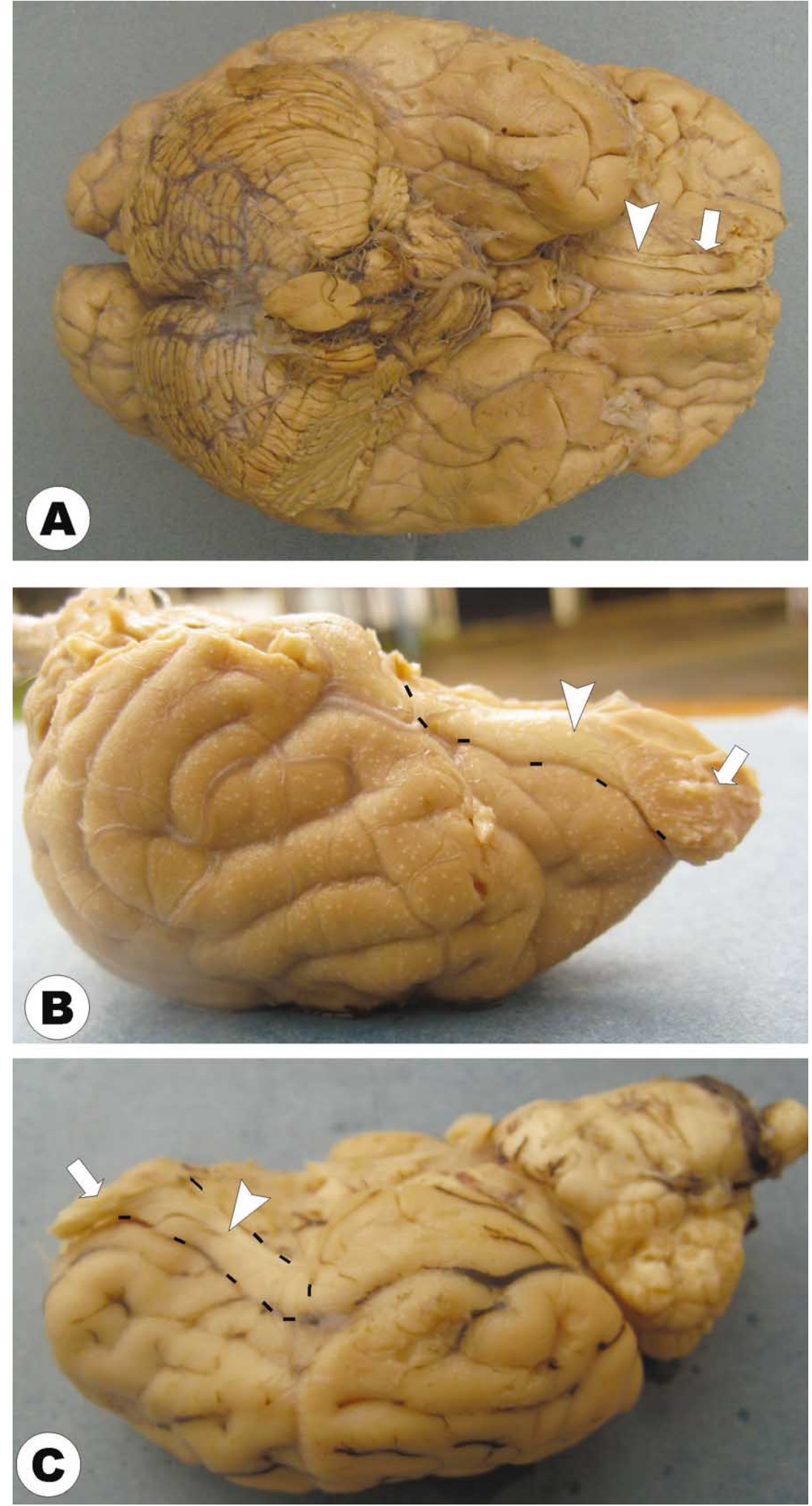

Fig. 2. Photographs of the inferior view of brain of the human (A) and lateral aspects of brains of the $\operatorname{dog}(\mathrm{B})$ and the goat (C) showing the olfactory bulb (arrows), olfactory tract and olfactory stria (arrow heads). The olfactory bulb overlies the olfactory tract, which continues posteriorly as the olfactory stria. 

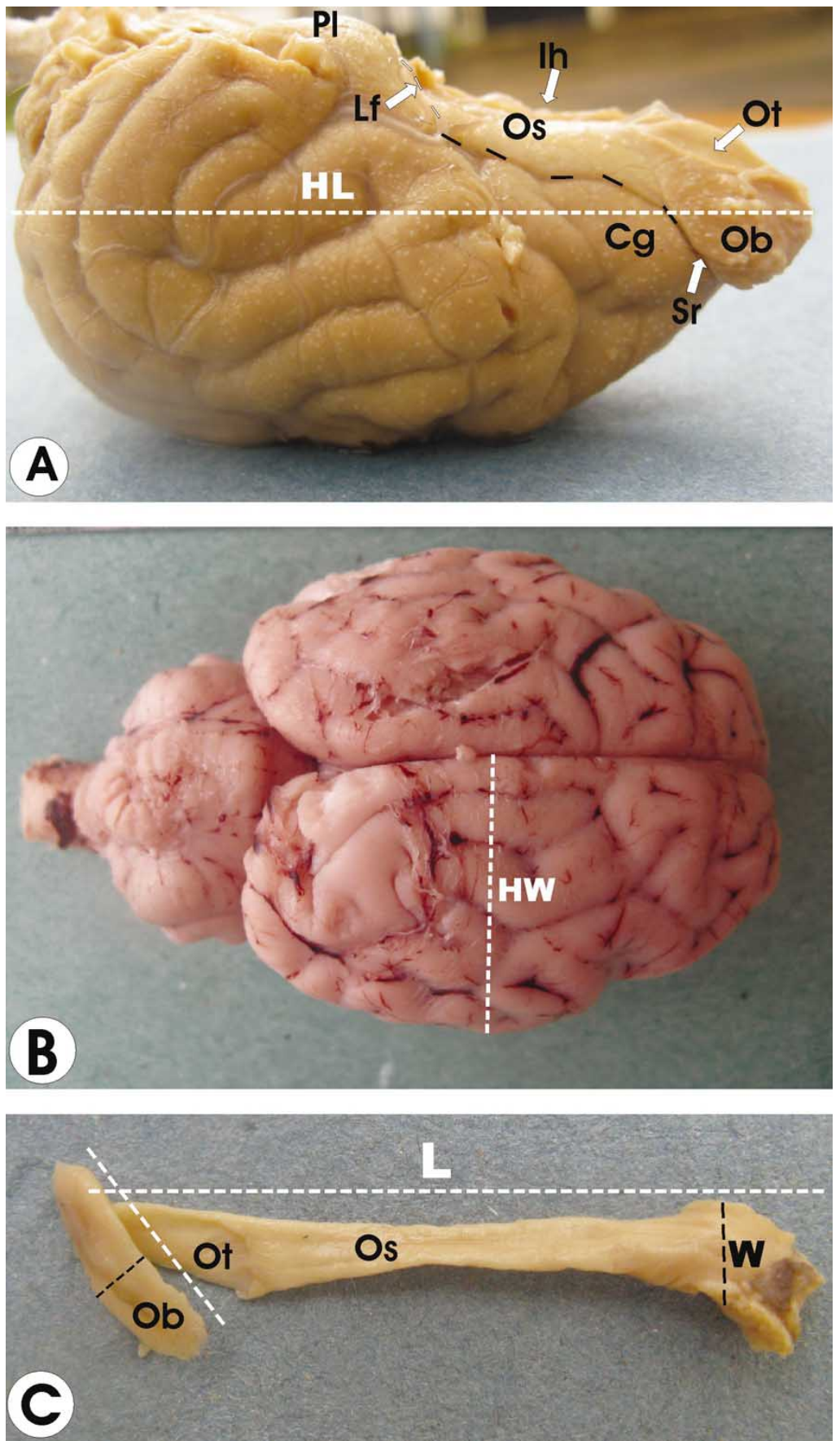

Fig. 3. Macrographs from the $\operatorname{dog}(\mathrm{A})$, goat $(\mathrm{B})$ and human $(\mathrm{C})$ outlining the dissection and measurement procedures on brains and components. (A) The greatest length of the cerebral hemisphere (HL) is taken from the lateral aspect of the brain. The olfactory bulb $(\mathrm{Ob})$, olfactory tract $(\mathrm{Ot})$ and stria $(\mathrm{Os})$ are then separated, as a block, from the lateral cerebral gyri $(\mathrm{Cg})$ by making a blunt dissection along sulcus rhinalis ( $\mathrm{Sr}$ ) and extending medially to reach the inner face of the cerebral hemispheres (Ih) and posteriorly to detach the block from the piriform lobe (Pl) along the lateral fossa (Lf). (B) The greatest width of the cerebral hemisphere (HW) is measured at its greatest points from the dorsal (superior) aspects of the brain. (C) The olfactory bulb $(\mathrm{Ob})$ is then detached from the underlying olfactory tract $(\mathrm{Ot})$ and the greatest lengths (L) and widths (W) of the olfactory stria (Os) and tract, and also that of bulb determined. and was least in the human $\left(0.06 \pm 0.01 \mathrm{~cm}^{3}\right)$ and the ratio of the volume of the bulb to that of the brain was highest in dogs $(0.31 \%)$ followed by goats $(0.18 \%)$ and humans $(0.01 \%)$ (Table I). The volume of the bulb, tract and stria was greatest in the dog $(1.15 \pm$ $\left.0.04 \mathrm{~cm}^{3}\right)$ compared to the goat $(0.75 \pm$ $\left.0.05 \mathrm{~cm}^{3}\right)$ and the human $\left(0.31 \pm 0.02 \mathrm{~cm}^{3}\right)$, and this accounted for $1.95 \%, 0.77 \%$ and $0.03 \%$, respectively, of the brain volume (Table I).

The greatest width (diameter) of olfactory bulb relative to that of the corresponding cerebral hemisphere gave the highest ratio in the dog $(42.91 \%)$ compared to the goat $(29.73 \%)$ and human $(8.94 \%)$ (Table II). Similarly, length proportion of the bulb, tract and stria to that of the hemisphere increased in the order of humans $(21.47 \%)$, goats $(51.87 \%)$ and dogs $(72.30 \%)$ (Table II).

Width measurement of olfactory bulb gave the highest value in dogs $(10.80 \pm 1.64)$ followed by goats $(8.25 \pm 0.96)$ and humans (5.50 \pm 0.71$)$ (Fig 4). Similarly, the width of the olfactory tract and stria declined from the $\operatorname{dog}(17.5 \pm 2.12)$, to goat $(15.5 \pm 0.71)$, to human (3.63 \pm 1.11$)$ (Fig 4).

Surprisingly, the length of the olfactory bulb was of greatest value in dogs (18.5 \pm $0.71)$ followed by humans $(15.25 \pm 0.96)$, while that of the goat was the smallest (13.5 \pm 0.70 ) (Fig 5). In a similar way, the length of the bulb together with that of the tract and stria declined in the order of dogs (48.2 \pm $1.92)$, humans $(36.25 \pm 1.71)$ and goats (34.50土 1.29) (Fig. 5).

\section{DISCUSSION}

The present paper analyses the morphometric parameters of olfactory bulb, tract and stria in the human (primate), dog (carnivore) and goat (herbivore) in relation to differences in olfactory functional needs. In these species, a comparison is made on the volumes and linear dimensions of the olfactory bulbs, olfactory tracts and striae and the proportions of the sizes of these structures relative to the cerebrum and the whole brain. 
Table I. Mean values of volumes of olfactory bulbs alone, olfactory bulbs, tract and stria combined and brains ( $\left.\mathrm{cm}^{3}\right)$, and their ratios $(\%)$ in the human, dog and goat. Values are presented as means $\pm \mathrm{SD}$ (given in parentheses). $n=5$ animals per species. OB, OT, OS stands for olfactory bulb, tract and stria respectively.

\begin{tabular}{|c|c|c|c|c|c|}
\hline \multirow{2}{*}{ Species } & \multicolumn{5}{|c|}{ VOLUMES $\left(\mathrm{cm}_{-}\right)$} \\
\hline & OB & OB, OT \& OS & Brain & $\begin{array}{c}\text { Ratio: OB to brain } \\
(\%)\end{array}$ & $\begin{array}{c}\text { Ratio: OB, OT \& OS } \\
\text { to brain (\%) }\end{array}$ \\
\hline Human & $0.06(0.01)$ & $0.31(0.02)$ & $1175.00(52.44)$ & 0.01 & 0.03 \\
\hline Dog & $0.18(0.02)$ & $1.15(0.04)$ & $58.98(3.01)$ & 0.31 & 1.95 \\
\hline Goat & $0.17(0.01)$ & $0.75(0.05)$ & $97.33(8.79)$ & 0.18 & 0.77 \\
\hline
\end{tabular}

Table II. Mean values of greatest diameters (widths) of olfactory bulbs and corresponding cerebral hemispheres and lengths of olfactory bulbs, tracts and stria and cerebrum $(\mathrm{mm})$ and their ratios $(\%)$ in the human, dog and goat. Mean values are presented with their standard deviations (given in parentheses). $n=5$ animals per species. OB, OT, OS denotes olfactory bulb, tract and stria respectively

\begin{tabular}{lcccccc}
\hline \multirow{2}{*}{ S pecies } & \multicolumn{3}{c}{ WIDTH $(\mathrm{mm})$} & \multicolumn{3}{c}{ LENGTH $(\mathrm{mm})$} \\
\cline { 2 - 7 } & OB & Hemisphere & Ratio $(\%)$ & OB, OT \& OS & Hemisphere & Ratio $(\%)$ \\
\hline Human & $5.50(0.71)$ & $61.50(2.02)$ & 8.94 & $36.25(1.70)$ & $168.86(10.53)$ & 21.47 \\
Dog & $10.8(1.64)$ & $25.17(0.76)$ & 42.91 & $48.20(1.92)$ & $66.67(1.53)$ & 72.30 \\
Goat & $8.25(0.96)$ & $27.75(1.77)$ & 29.73 & $34.5(1.30)$ & $66.50(2.12)$ & 51.87 \\
\hline
\end{tabular}

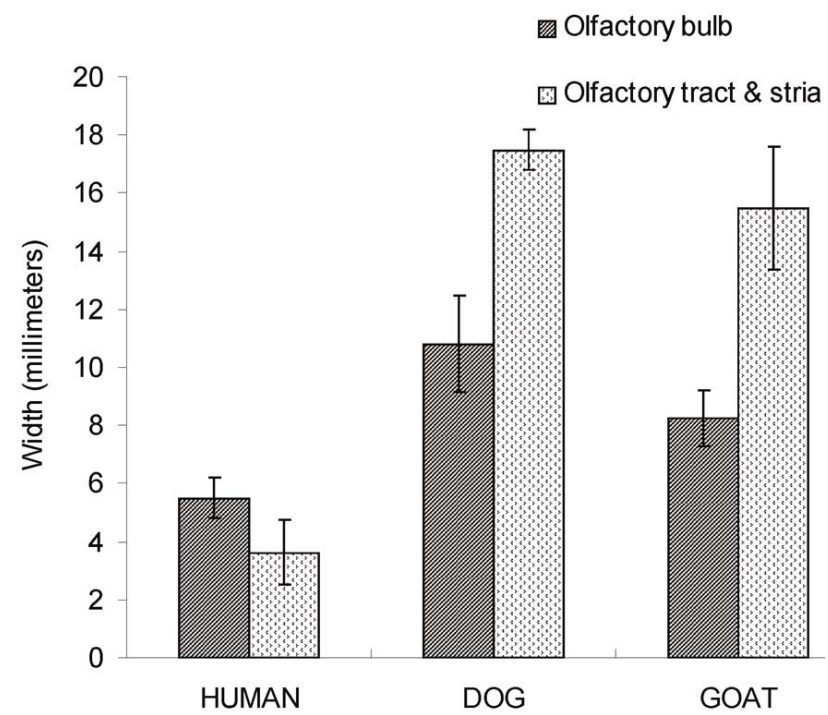

Fig. 4. Mean widths ( $\mathrm{mm}$ ) of olfactory bulbs and olfactory tracts and striae. The widths of the bulbs and also that of the tract and stria show the highest value in dogs followed by goats and humans, $\mathrm{p}<0.05$.

We hypothesize that the sizes of these structures correlate with the olfactory functional needs and therefore the lifestyles of these animals.

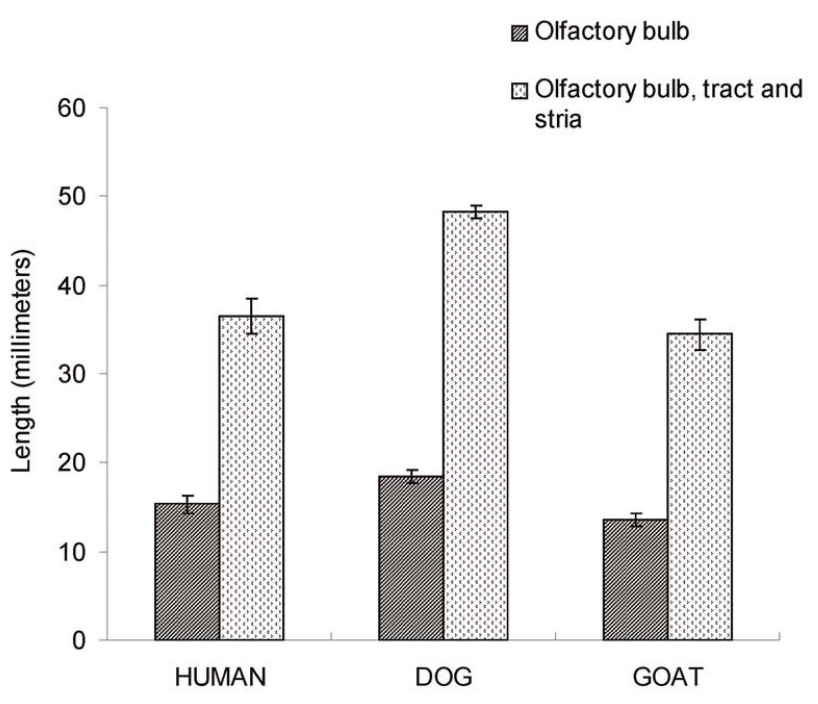

Fig. 5. Mean lengths $(\mathrm{mm})$ of olfactory bulb and also that of the olfactory bulb together with the tract and stria. The length of the bulbs alone, and also that of the bulb, tract and striae are of greatest value in dogs followed by humans, and is least in the goat, $\mathrm{p}<0.05$.

The olfactory bulb provides one of the direct links between the peripherally located olfactory receptors and the primary olfactory cortex and therefore offers connection 
between the brain and the environment (Turetsky et al., 2000). In a recent study (Kavoi et al., 2010), it was shown that the structure of the primary olfactory cells are structurally designed in a way that meets the olfactory functional challenges. It therefore seems probable that the size of the olfactory bulb also reflects on the level of dependency on olfaction for survival in a given species.

The present work shows that the volume of the olfactory bulb and its projection structures (olfactory tract and striae) is greatest (both in isolation and as a percentage of whole brain) in dogs followed by goats and humans. Given that a larger olfactory bulb volume is indicative of better olfactory function (Haehner et al., 2008), it is possible that the volume of the bulb directly relates with the functional needs and therefore the behavioral ecology of the above species.

The greatest width (diameter) of olfactory bulb and also the ratio of the width of the bulb to that of corresponding cerebral hemisphere increase from the humans, to goat, to dog. This seems to match with reports on birds (Bang \& Cobb, 1968) where olfactory bulb to hemisphere width ratios were $4 \%$ in the house sparrow, $15 \%$ in the domestic fowl and $28.7 \%$ in the Turkey vulture (a carnivorous bird). These proportion differences were attributed to the varied degrees of olfactory dependency on feeding in the birds.

Length proportion of the olfactory bulb, tract and stria to that of the hemisphere increases in the order of human, goat and dog. Surprisingly, individual length measurement of the bulb alone and also the bulb together with the tract and stria gives the highest values in the dog followed by human, and the lowest value in the goat. In the dog, the long olfactory bulb, tract and stria may have resulted from the characteristic narrowing and lengthening of the cerebral hemispheres at the level of the anterior poles (Sisson and Grossman). In humans, it is likely that the exceptionally large frontal lobes (Caviness et al., 1996) overlie these structures to make them fairly long.

The evolution of specific brain parts conforms to the functional needs and life-styles of a given species (Kaas \& Collins). The human brain is dominated by a large visual cortex meant for accurate distance perception (binocular vision) required in brachiation (Pough et al.). Therefore, the reduction in size of the olfactory structures in the human is likely to be an evolutionary trend which may have resulted from the reduced use of the sense of smell owing to the arboreal life and thus the need for a tactile and a visually dominant sensory system.

The dog senses are attuned for a wide range of activities including food searching (tracking and catching prey) and reproduction (Walker; Gittleman, 1989) and therefore require a markedly large olfactory cortex (Coren, 2004) as well as a prominent olfactory bulb. In the goat, however, the role of olfaction has been narrowed down to cater for reproductive activities including mating and estrus (Gelez \& Fabre-Nys) and mother-neonate interaction (Lévy et al.). This may explain why the olfactory structures are relatively less prominent.

In conclusion, the present study shows that the morphometric modification of the olfactory bulb, tract and stria decline from the dog, to goat, to human, and thereby reflects on the olfactory functional requirements and consequently the ecological and evolutionary behaviors of these species. In a study of this kind, the dissection of the olfactory parts out from formalin fixed brains is likely to be an inevitable source of minor error (Bang \& Cobb). However, this study serves to adequately elucidate key morphometric features of the olfactory brain that predicts on the variations in dependency on olfaction for survival among primates, carnivores and herbivores. Moreover, the study provides background data for future work involving more species and techniques.

\section{ACKNOWLEDGEMENTS}

We thank the departments of Human Anatomy, and Veterinary Anatomy \& Physiology of the University of Nairobi for the provision of human and animal brains respectively. The excellent technical assistance accorded to us by Messrs John Kiai and Peter Irungu of the Departments of Veterinary Anatomy and Physiology, University of Nairobi, and Mrs Dorcas Nduati of the Department of Public Health, Pharmacology and Toxicology, University of Nairobi, are highly appreciated.

KAVOI, B. M. \& JAMEELA, H. Morfometría comparada del bulbo, tracto y estría olfatoria en el humano, perro y cabra. Int. J. Morphol., 29(3):939-946, 2011.

RESUMEN: Los parámetros morfométricos de los componentes del cerebro olfativo presentan variaciones que dependen de las especies. Sin embargo, la asociación de estos parámetros con la función olfativa vis-à-vis los comportamientos ecológicos y evolutivos es poco conocida. En este estudio se llevó a cabo un análisis morfométrico del bulbo, tracto y estría olfatoria en tres animales de diversidad ecológica que abarcan los seres humanos (primates), perros (carnívoros) y cabras (herbívoros) para dilucidar las diferencias en la morfometría en relación con la función 
olfatoria. El uso de cerebros fijados en formalina, los volúmenes y las medidas lineales de las estructuras olfativas se determinaron y se correlacionaron con el cerebro. El volumen del bulbo olfatorio fue mayor en los perros, seguidos por cabras y seres humanos y constituyeron un $0,31 \%$, $0,18 \%$ y $0,01 \%$, respectivamente, del volumen del cerebro. Del mismo modo, la relación entre el volumen del bulbo, vías y estrías al del cerebro fue de $1,95 \%$ en el perro, un $0,77 \%$ en la cabra y $0,03 \%$ en el ser humano. El ancho del bulbo fue mayor $(\mathrm{p}<0,05)$ en los perros $(10,80 \pm 1.64 \mathrm{~mm})$ en comparación con cabras $(8,25 \pm 0.96 \mathrm{~mm})$ y humanos $(5,50 \pm 0.71 \mathrm{~mm})$, y representó una total hemisférico de $42,91 \%, 29,73 \%$ y $8,94 \%$ respectivamente. Sin embargo, curiosamente la longitud total del bulbo olfatorio, del tracto y estrías aumentaron en la cabra $(34,5 \pm 1,30 \mathrm{~mm})$, en humanos $(36,25 \pm 1.70 \mathrm{~mm})$ y en el perro $(48,20 \pm 1,92 \mathrm{~mm})$, y constituyeron $21,47 \%, 51,87 \%$ y $72,30 \%$, respectivamente, del largo del hemisferio. Estos resultados sugieren que las adaptaciones morfométricas de los componentes olfativos de la función olfativa se van reduciendo de perro a cabra y al hombre y esto puede ser indicativo de las variadas necesidades funcionales olfativas en lo que respecta a la diversidad ecológica de estas especies.

PALABRAS CLAVE: Morfometría; Cerebro olfactorio; Humano; Perro; Cabra.

\section{REFERENCES}

Bang, B. G. \& Cobb, S. The size of the olfactory bulb in 108 species of birds. Auk, 85:55-61, 1968.

Barton, R. A. Primate brain evolution: Integrating comparative neurophysiological and ethological data. Evol. Anthropol., 15(6):224-36, 2006.

Barton, R. A. The evolutionary ecology of the primate brain. In: Lee, P., (Ed.), Comparative Primate Socioecology. Cambridge University Press, United Kingdom, 1999. pp. 167-203.

Barton, R. A.; Purvis, A. \& Harvey P. H. Evolutionary radiation of visual and olfactory brain systems in primates, bats and insectivores. Phil. Trans. R. Soc. Lond. B., 348:381-92, 1995.

Byanet, O.; Onyeanusi, B.I. \& Ibrahim, N.D.G. Sexual dimorphism with respect to the macro-morphometric investigations of the forebrain and cerebellum of the grasscutter (Thryonomys swinderianus). Int. J. Morphol., 27:361-5, 2009.
Caviness, V. S. J.; Kennedy, D. N.; Bates J. \& Makris, N. The developing human brain: A morphometric profile. In: Thatcher, R. W., Lyon, G. R., Rumsey J. \& Krasnegor, N. (eds.), Developmental Neuroimaging: Mapping the Development of Brain and Behavior. Academic Press, New York, 1996. pp. 3-14.

Coren, S. How Dogs Think: Understanding the Canine Mind. Simon and Schuster, New York, 2004.

Field, P. M.; Li, Y. \& Raisman, G. Ensheathment of the olfactory nerves in the adult rat. J. Neurocytol., 32:31724, 2003.

Finlay, B. L. \& Darlington, R. B. Linked regularities in the development and evolution of mammalian brains. Science, 268:1578-84, 1995.

Gelez, H. \& Fabre-Nys, C. The "male effect" in sheep and goat: a review of the respective roles of the olfactory systems. Horm. Behav., 46:257-71, 2004.

Gittleman, J. L. Carnivore olfactory bulb size: allometry, phylogeny and ecology. J. Zool., 225:253-72, 1991.

Gittleman, T. L. Carnivore Behavior, Ecology and Evolution. London, Chapman and Hall Ltd., 1989.

Haehner, A.; Rodewald, A.; Gerber, J. C. \& Hummel, T. Correlation of olfactory function with changes in the volume of the human olfactory bulb. Arch. Otolaryngol. Head Neck Surg., 134:621-4, 2008.

Heine, O. \& Galaburda, A. M. Olfactory asymmetry in the rat brain. Exp. Neurol., 91:392-8, 1986.

Hirano, Y.; Ogawa, Y. \& Motokizawa, F. A morphometric rightleft comparison of the cat olfactory bulb. Okajimas Folia Anat. Jpn., 66:265-9, 1989.

Kaas, J. H. \& Collins, C. E. Evolving ideas of brain evolution. Nature, 411:141-2, 2001

Kaas, J. H. Why is brain size so important: design problems and solutions as neocortex gets bigger or smaller. Brain and Mind, 1:7-23, 2000.

Kavoi, B., Makanya, A., Hassanali, J., Carlsson, H. \& Kiama, S. Comparative functional structure of the olfactory mucosa in the dog and the sheep. Ann. Anat., 192:329-37, 2010.

Kruska, D. Mammalian domestication and its effect on brain structure and behavior. In: Jerison, H. J. \& Jerison, I. 
(eds.), The Evolutionary Biology of Intelligence. Springer-Verlag, Heidelberg, 1988. pp. 211-50.

Lévy, F.; Keller, M. \& Poindron, P. Olfactory regulation of maternal behavior in mammals. Horm. Behav., 46:284302, 2004.

Meisami, E. \& Bhatnagar, K. P. Structure and diversity in mammalian accessory olfactory bulb. Microsc. Res. Tech., 43:476-99, 1998.

Pough, F. H.; Janis, C. M. \& Heiser, J. B. Vertebrate Life. $8^{\text {th }}$ ed. Benjamin Cummings, California, 2005.

Ross, C. F. Allometric and functional influences on primate orbit orientation and the origins of the Anthropoidea. $J$. Hum. Evol., 29:201-27, 1995.

Scherle, W. A simple method for volumetry of organs in quantitative stereology. Mikroskopie, 26:57-60, 1970.

Sisson, S. \& Grossman, J. D. The Gross Anatomy of the Domestic Animals. $4^{\text {th }}$ ed. W.B. Philadelphia and London, Saunders Company, 1953.

Turetsky, B. I.; Moberg, P. J.; Yousem, D. M.; Doty, R. L.; Arnold, S. E. \& Gur, R. E.. Reduced olfactory bulb volume in patients with schizophrenia. Am. J. Psychiatry, 157(5):828-30, 2000

Turetsky, B. I.; Moberg, P. J.; Arnold, S. A.; Doty, R. L. \& Gur, R. E. Low olfactory bulb volume in 1st-degree relatives of patients with schizophrenia. Am. J. Psychiatry, 160:703-8, 2003.

Walker, E. P. Mammals of the World. $3^{\text {rd }}$ ed. Baltimore and London, The Johns Hopkins University Press, 1975.
Correspondence to:

Boniface Kavoi University of Nairobi

Department of Veterinary Anatomy \& Physiology Riverside Drive,

P.O Box 30197

Nairobi

KENYA

Tel.: +254024451770

Fax: +254024451770

E-mail: drkanvo@yahoo.com

Received: 19-01-2011

Accepted: 19-04-2011 